INTERNATIONAL JOURN AL OF RESEARCHES IN BIOSCIENCES, AGRICULTURE AND TECHNOLOGY (c) VISHWASHANTI MULTIPURPOSE SOCIETY (Global Peace Multipurpose Socie ty) R. No. MH-659/13(N) www.vmsindia.org

\title{
FOLK MEDICINAL THERAPY USED IN THE TREATMENT OF RENAL CALCULI (KIDNEY STONE) IN MAHARASHTRA: A REVIEW
}

\section{Ravindrakumar Sahebrao Dhande}

Department of Botany, Shri Shivaji Arts, Commerce and Science College, Akot. Dist. Akola (M.S.) India.

\section{Abstract} ravi_dhande2005@yahoo.co.in

Medicinal plants have been known from time immemorial and are highly known all ove $r$ the world as a rich source of the rapeutic agents for the prevention of various ailments. Today a large number of people are suffering from kidney ailments like Ne phrolithiasis, Ureterolithiasis and Urolithiasis. This causes serious health problems such as severe pain, urinary-tract obstruction and infection that adversely affect well-be ing of the individuals. Many synthetic drugs like diuretics and narcotic analgesics are being used in treatment of kidney stone but overuse of synthetic drugs, which results in higher incidence of adverse drug reactions have motivated humans to return to nature for safe remedies. In the present article, an attempt has been made to emphasis on kidney stones that can be treated by folk medicinal plants from diffe rent regions of Maharashtra.

Keywords: Medicinal plants, Kidney Stones, Maharashtra

\section{Introduction:}

The kidneys are

beanshaped organs found on the left and right sides of the body in vertebrates. They filter the blood in order to make urine, to release and retain water, and to remove waste. They also control the ion concentrations and acid-base balance of the blood. Each kidney feeds urine in to the bladder by means ureter. When the bladder fills, there is an urge to urinate, and the bladder empties through the urethra. Occasionally, waste products in the kidneys can form crystals that collect around the inside of the kidney. Over time, the crystals may build up to form a hard stone-like lump called kidney stone. The acid-base balance $(\mathrm{pH})$ of the urine and the concentration of minerals and chemicals within the urine are all factors that can signify the formation of a stone. Concentrated urine often occurs during an episode of dehydration, setting the stage for the beginning of stone formation. Kidney stone causes pressure and swelling within the kidney. It causes pain that starts from the lower back and radiates to the front of abdomen. The severity of the pain does not depend on the size of the stone, but it rather depends on the amount of obstruction and Kidney swelling. If not treated the intense pain would be continuous and would considerably increase.

Medicinal plants have been known from time immemorial and are highly known all over the world as a rich source of therapeutic agents for the prevention of various ailments. Many plants have been used for the treatment of kidney stones in traditional syste $m$ of medicine throughout the world. Indeed along with dietary measures, plant preparation formed the basis of treatment of various diseases until the introduction of allopathic medicine. Ethnobotany and ethnopharmacology has been seen as a tool for drug discovery (Schultes 1962), a mode of asce rtaining conse rvation (Cox 1997).

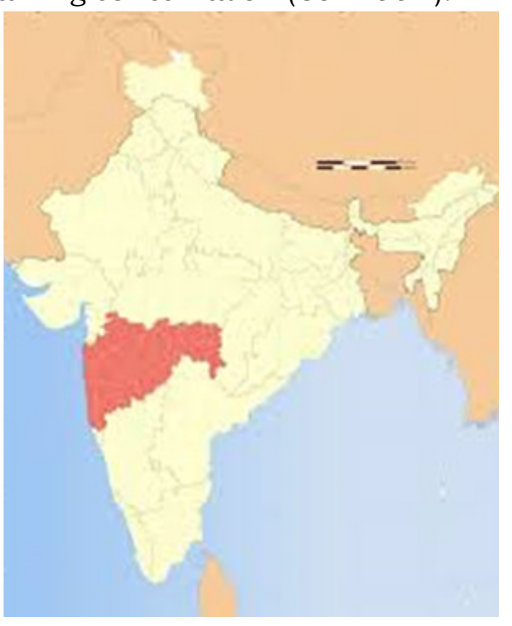

Figure 1: Map of India (Location of Maharashtra shown in red)

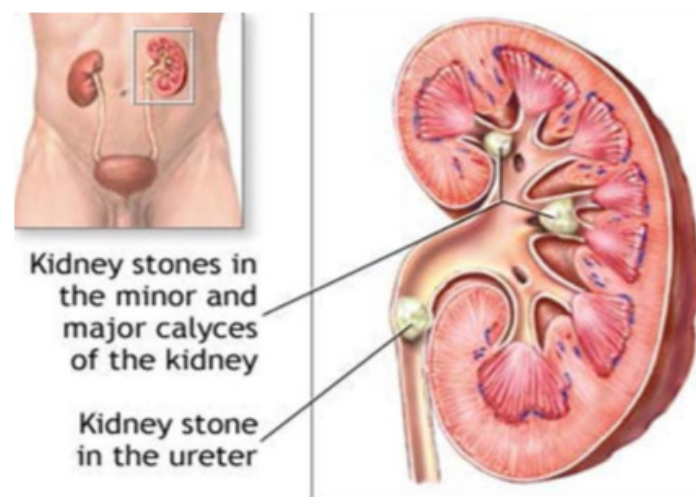

Figure 2: Internal structure of Kidney and positions of Kid ney Stones 
Table: List of Medicinal Plants used in Maharashtra on Kidney Stone.

\begin{tabular}{|c|c|c|c|c|c|}
\hline S.N & Botanical name & Family name & Local name & $\begin{array}{l}\text { Plant part/s used and } \\
\text { administration of a drug }\end{array}$ & Ref. \\
\hline 1 & $\begin{array}{l}\text { Abutilon } \\
\text { indicum (Link) } \\
\text { Sweet }\end{array}$ & Malvaceae & $\begin{array}{l}\text { Mudra, Petari, } \\
\text { Atibala }\end{array}$ & Root bark. & 19 \\
\hline 2 & $\begin{array}{l}\text { Acacia arabica } \\
\text { L. }\end{array}$ & Mimosaceae & Babul & Stem bark, Gum, Fruits. & 19 \\
\hline 3 & $\begin{array}{l}\text { Acacia catechu } \\
\text { Willd }\end{array}$ & Mimosaceae & Khair & Stem Bark, Resinous extract. & 19 \\
\hline 4 & $\begin{array}{l}\text { Achyranthes } \\
\text { aspera L. }\end{array}$ & Amaranthaceae & Aghada & Leaves. & 15 \\
\hline 5 & $\begin{array}{l}\text { Adhatoda } \\
\text { vasica Medic. }\end{array}$ & Acanthaceae & Adulsa & Whole plant. & 19 \\
\hline 6 & $\begin{array}{l}\text { Aegle mormelos } \\
\text { L. }\end{array}$ & Rutaceae & Bel & Root. & 19 \\
\hline 7 & Aerva lanata L. & Amaranthaceae & $\begin{array}{l}\text { Kapurmadhura, } \\
\text { Mhatari, } \\
\text { Kuprui, } \\
\text { Gorakhbuti }\end{array}$ & $\begin{array}{l}\text { - Inflorescence. } \\
\text { - Decoction of complete } \\
\text { plant is used. } \\
\text { - Whole plant is used for } \\
\text { treatment of } \\
\text { maintaining blood sugar } \\
\text { to optimum level and } \\
\text { removing stones from } \\
\text { kidneys. }\end{array}$ & $\begin{array}{l}4 \\
12 \\
15 \\
24\end{array}$ \\
\hline 8 & $\begin{array}{l}\text { Amaranthus } \\
\text { caudatus L. }\end{array}$ & Amaranthaceae & Rajgira & Leaves extract is give $n$. & 3 \\
\hline 9 & $\begin{array}{l}\text { Amaranthus } \\
\text { viridis L. }\end{array}$ & Amaranthaceae & Chawali & All parts of the plant. & 3 \\
\hline 10 & $\begin{array}{l}\text { Amarathus } \\
\text { spinosa L. }\end{array}$ & Amarantaceae & Katemath & $\begin{array}{l}1-2 \text {-gm of stem ash powder with } \\
\text { water is taken internally for } 1-2 \\
\text { weeks. }\end{array}$ & 21 \\
\hline 11 & $\begin{array}{l}\text { Anogeissus } \\
\text { latifolia (Roxb. } \\
\text { ex.DC.) }\end{array}$ & Combretaceae & Dhawada & Stem bark. & 19 \\
\hline 12 & $\begin{array}{l}\text { Asparagus } \\
\text { racemosus } \\
\text { Willd. }\end{array}$ & Liliaceae & Shatmuli & Tender shoots. & 19 \\
\hline 13 & $\begin{array}{l}\text { Azadirachta } \\
\text { indica A.Juss. }\end{array}$ & Meliaceae & Kaduneem & Stem bark, Le aves. & 19 \\
\hline 14 & $\begin{array}{l}\text { Baliospermum } \\
\text { montanum }\end{array}$ & Euphorbiaceae & Danti & Root, leaves and seeds & 4 \\
\hline 15 & Basella alba L. & Basellaceae & Velbandi & $\begin{array}{l}\text { - Flowers. } \\
\text { - Whole plant. }\end{array}$ & $\begin{array}{l}18 \\
19\end{array}$ \\
\hline 16 & $\begin{array}{l}\text { Bauninia } \\
\text { racemosa Lam. }\end{array}$ & Caesalpiniaceae & Apta & Stem bark. & 19 \\
\hline 17 & Beta vulgaris L. & Amaranthaceae & Beet & $\begin{array}{l}\text { Daily two glass of rhizome juice } \\
\text { is given. }\end{array}$ & 3 \\
\hline 18 & $\begin{array}{l}\text { Biophytum } \\
\text { sensitiuum (L.) } \\
\text { DC. }\end{array}$ & Oxalidaceae & Lajalu & $\begin{array}{l}\text { - Decoction of root is given } 3 \\
\text { times a day. } \\
\text { - Fresh leaves decoction is } \\
\text { taken in morning and } \\
\text { evening. } \\
\text { - Whole plant. }\end{array}$ & $\begin{array}{l}8 \\
19\end{array}$ \\
\hline 19 & Bombax ceiba L. & Bombacaceae & Kate-sawar & $\begin{array}{l}\text { - Dry fruit is used in the form } \\
\text { of extract or powder before } \\
\text { breakfast daily. } \\
\text { - Bark powder } 5 \text { gms } 3 \text { times a } \\
\text { day is useful for urination. }\end{array}$ & 8 \\
\hline
\end{tabular}




\begin{tabular}{|c|c|c|c|c|c|}
\hline 20 & $\begin{array}{l}\text { Borhrravia } \\
\text { diffusa L. }\end{array}$ & Nyctaginaceae & $\begin{array}{l}\text { Punarnava, } \\
\text { Raktavasu }\end{array}$ & $\begin{array}{l}\text { - Whole plant is used for } \\
\text { treatment of asthma and } \\
\text { kidney stone. } \\
\text { - Roots are boiled with the milk } \\
\text { and are taken. } \\
\text { - Root decoction is given daily } \\
\text { for one month. }\end{array}$ & $\begin{array}{l}3 \\
12\end{array}$ \\
\hline 21 & $\begin{array}{ll}\text { Bridelia } & \text { retusa } \\
\text { Sprang } & \\
\end{array}$ & Euphorbiaceae & Ftthar fode & Leaves. & 4 \\
\hline 22 & $\begin{array}{l}\text { Bryophyllum } \\
\text { pinnatum (Lam.) } \\
\text { Oken }\end{array}$ & Crassulaceae & Amti, Panphuti & Leaves. & 19 \\
\hline 23 & $\begin{array}{l}\text { Butea } \\
\text { monosperma } \\
\text { (Lam.) Taub. }\end{array}$ & Fabaceae & Palas & $\begin{array}{l}\text { - Leaves juice or decoction is } \\
\text { useful. } \\
\text { - Seed powder in one teaspoon } \\
\text { after meals is taken. }\end{array}$ & $\begin{array}{l}8 \\
11\end{array}$ \\
\hline 24 & $\begin{array}{l}\text { Caesalpinia } \\
\text { bonduc (L.) }\end{array}$ & Caesalpiniaceae & Sagargoti & Fruits. & 19 \\
\hline 25 & Cassia fistula L. & Caesalpinioideae & & $\begin{array}{l}\text { Fruit powder is given with wate } r \\
\text { for } 3-4 \text { months. }\end{array}$ & 3 \\
\hline 26 & $\begin{array}{l}\text { Celastrus } \\
\text { paniculata } \\
\text { Willd. }\end{array}$ & Celastraceae & Mal kanguni & $\begin{array}{l}\text { Fresh leaves crushed and mixed } \\
\text { with curd are given before } \\
\text { breakfast-no intake except } \\
\text { water up to } 3 \mathrm{pm} \text {. }\end{array}$ & 8 \\
\hline 27 & $\begin{array}{l}\text { Celosia argentia } \\
\text { L. }\end{array}$ & Amaranthaceae & Kurdu & $\begin{array}{l}\text { - Root decoction if taken in } \\
\text { morning gives good results. } \\
\text { - Seed powder taken in a gap of } \\
4 \text { hours, gives very good } \\
\text { results. } \\
\text { - Two teaspoon root extract is } \\
\text { mixed with } 5 \mathrm{~g} \text { sugar candy } \\
\text { and } 2 \mathrm{~g} \text { Jire (Cuminum } \\
\text { cyminum) powder and it is } \\
\text { given early in the morning for } \\
\text { seven days. } \\
\text { - One tablespoonful seeds are } \\
\text { powdered and this is boiled in } \\
300 \text { ml of water until it } \\
\text { reduces to } 75 \text { ml. this is then } \\
\text { administered twice a day for } 7 \\
\text { to } 10 \text { days. }\end{array}$ & $\begin{array}{l}1 \\
6 \\
8 \\
20\end{array}$ \\
\hline 29 & $\begin{array}{l}\text { Celosia cristata } \\
\text { L. } \\
\text { Chenopodium } \\
\text { album L. }\end{array}$ & $\begin{array}{l}\text { Amaranthaceae } \\
\text { Chenopodiaceae }\end{array}$ & $\begin{array}{l}\text { Kurdu } \\
\text { Chandan batava }\end{array}$ & $\begin{array}{l}\text { Root extract. } \\
\text { Whole plant. }\end{array}$ & $\begin{array}{l}16 \\
19\end{array}$ \\
\hline 30 & $\begin{array}{l}\text { Commiphora } \\
\text { mukul (Stocks) } \\
\text { Hook. }\end{array}$ & Burseraceae & Gugal & Gum. & 4 \\
\hline 31 & $\begin{array}{l}\text { Cordia } \\
\text { dichotoma (L.) }\end{array}$ & Boraginaceae & Bhokar & Stem Bark, Fruits. & 19 \\
\hline 32 & $\begin{array}{l}\text { Coriandrum } \\
\text { sativum L. }\end{array}$ & Umbelliferae & Dhaniya & Leaves and fruits. & 4 \\
\hline 33 & $\begin{array}{l}\text { Costus } \\
\text { speciosus } \\
\text { (koen.) }\end{array}$ & Costaceae & Khambari & $\begin{array}{l}\text { Decoction of tubers is taken } \\
\text { orally. }\end{array}$ & 3 \\
\hline 34 & $\begin{array}{l}\text { Crataeva } \\
\text { religiosa Forst. } \\
\text { f. }\end{array}$ & Capparaceae & Varun & Bark and leaves. & $\begin{array}{l}22 \\
4\end{array}$ \\
\hline
\end{tabular}




\begin{tabular}{|c|c|c|c|c|c|}
\hline 35 & $\begin{array}{l}\text { Crateva } \\
\text { adansonii }\end{array}$ & Capparaceae & Waiwarna & $\begin{array}{l}\text { Bark is used in the form of } \\
\text { powder or decoction before } \\
\text { breakfast. }\end{array}$ & 8 \\
\hline 36 & $\begin{array}{l}\text { Cucumis sativus } \\
\text { L. }\end{array}$ & Cucurbitaceae. & Kakadi & $\begin{array}{l}5 \mathrm{~g} \text { seed powder is mixed with } 5 \mathrm{~g} \\
\text { of Jire (Cuminum cyminum) } \\
\text { powder and } 5 \mathrm{~g} \text { sugar and it is } \\
\text { given along with water twice a } \\
\text { day for three days. }\end{array}$ & 6 \\
\hline 37 & $\begin{array}{l}\text { Cynodon } \\
\text { dactylon (L.) }\end{array}$ & Poaceae & Durva & Whole plant. & 19 \\
\hline 38 & Datura Metel L. & Solanaceae & Dhotara & Leaves and flowers. & 4 \\
\hline 39 & $\begin{array}{l}\text { Daucas carota } \\
\text { L. }\end{array}$ & Apiaceae & Gajar & $\begin{array}{l}\text { One glass juice is given fornight } \\
\text { to re move kidney stone. }\end{array}$ & 3 \\
\hline 40 & $\begin{array}{l}\text { Dioscorea } \\
\text { bulbifera L. }\end{array}$ & Dioscoreaceae & Manakund & Tubers. & 19 \\
\hline 41 & $\begin{array}{l}\text { Dolichosbiflorus } \\
\text { L. }\end{array}$ & Fabaceae & Kulith & Seeds. & 4 \\
\hline 42 & $\begin{array}{l}\text { Drimia indica } \\
\text { (Roxb.) }\end{array}$ & Asparagaceae & Jungli piyaz & $\begin{array}{l}\text { Bulb extract is useful in } \\
\text { morning before breakfast. }\end{array}$ & 8 \\
\hline 43 & Eclipta alba L. & Asteraceae & Bhrangarajah & Whole plant. & 4 \\
\hline 44 & $\begin{array}{l}\text { Enicostema } \\
\text { axillare (Poir. ex } \\
\text { Lam.) }\end{array}$ & Gentianaceae & Nai, Naya & $\begin{array}{l}20 \mathrm{~g} \text { plant powder is mixed with } \\
20 \mathrm{~g} \text { seed powder of Sag (Tectona } \\
\text { grandis) along with water. It is } \\
\text { given orally twice a day for } 4 \\
\text { days. }\end{array}$ & 6 \\
\hline 45 & $\begin{array}{l}\text { Ensete } \\
\text { superbum } \\
\text { (Roxb.) }\end{array}$ & Musaceae & Jangli keli & $\begin{array}{l}\text { Half foot peduncle is eaten raw } \\
\text { which leads to excessive } \\
\text { urination and gets relief from } \\
\text { kidney stone. }\end{array}$ & 7 \\
\hline 46 & $\begin{array}{l}\text { Gardenia } \\
\text { resinifera Roth }\end{array}$ & Rubiaceae & Dikemali & $\begin{array}{l}\text { One teaspoon fruit powder is } \\
\text { given twice a day for three days. }\end{array}$ & 6 \\
\hline 47 & $\begin{array}{l}\text { Gmelina arborea } \\
\text { Roxb. }\end{array}$ & Verbenaceae & Shivan & Roots. & 19 \\
\hline 48 & $\begin{array}{l}\text { Hemidesmus } \\
\text { indicus (L.) R. } \\
\text { Br. }\end{array}$ & Apocynaceae & Anantmul & $\begin{array}{l}\text { - Root powder is given daily } \\
\text { morning, afte rnoon and } \\
\text { evening. } \\
\text { - Leaf decoction is used in } \\
\text { morning and evening. }\end{array}$ & 8 \\
\hline 49 & $\begin{array}{l}\text { Holarrhena } \\
\text { antidysenterica } \\
\text { (Linn.) Wall }\end{array}$ & Apocynaceae & Pandhra kuda & $\begin{array}{l}10 \mathrm{~g} \text { bark powder is mixed with } \\
50 \mathrm{ml} \text { curd and it is given orally } \\
\text { twice a day for one week. }\end{array}$ & 6 \\
\hline 50 & $\begin{array}{l}\text { Holarrhena } \\
\text { pubescens Wall, } \\
\text { ex G.Don. }\end{array}$ & Apocynaceae & $\begin{array}{l}\text { Pandhara kuda, } \\
\text { Indrajaw }\end{array}$ & $\begin{array}{l}\text { - Internal bark powder one } \\
\text { teaspoon in morning and } \\
\text { evening. } \\
\text { - Stem powder used before } \\
\text { meals. } \\
\text { - Seed powder is taken before } \\
\text { breakfast. }\end{array}$ & 8 \\
\hline 51 & $\begin{array}{l}\text { Hygrophila } \\
\text { auriculata (Sch.) } \\
\text { Heine }\end{array}$ & Acanthaceae & Talimkhana & Roots. & 19 \\
\hline 52 & $\begin{array}{l}\text { Kalanchoe } \\
\text { pinnata (Lam.) }\end{array}$ & Craussulaceae & Panphuti & $\begin{array}{l}\text { Fresh leaves juice is given at } \\
\text { any time. }\end{array}$ & 8 \\
\hline 53 & $\begin{array}{l}\text { Lagenaria } \\
\text { siceraria } \\
\text { (Molina) Standl. }\end{array}$ & Cucurbitaceae & Dudhi bhopla & $\begin{array}{l}\text { One cup of fruit juice is advised } \\
\text { twice a day for seven days. }\end{array}$ & 6 \\
\hline 54 & $\begin{array}{l}\text { Lagerstroemia } \\
\text { parviflora L. }\end{array}$ & Lythrace ae & Lendya & $\begin{array}{l}\text { Roots are crushed and } 1-2 \text { gms } \\
\text { are swallowed once a day, till } \\
\text { gets rid of kidney stone. }\end{array}$ & 21 \\
\hline 55 & $\begin{array}{l}\text { Lawsonia } \\
\text { inermis L }\end{array}$ & Lythrace ae & Mendi & Leaves. & 9 \\
\hline
\end{tabular}




\begin{tabular}{|c|c|c|c|c|c|}
\hline 56 & \begin{tabular}{ll|} 
Luffa \\
acutangula \\
Roxb.
\end{tabular} & Cucurbitaceae & Dodka & $\begin{array}{l}\text { Two teaspoon root extract is } \\
\text { given thrice a day for three } \\
\text { days. }\end{array}$ & 6 \\
\hline 57 & $\begin{array}{l}\text { Macratyloma } \\
\text { uniflorum (Lam.) }\end{array}$ & Fabaceae & Kulthi, Kulith & $\begin{array}{l}\text { Boiled Fruits with cold water is } \\
\text { given thrice a day. }\end{array}$ & 8 \\
\hline 58 & $\begin{array}{l}\text { Madhuka } \\
\text { longifolia } \\
\text { (J.Konig) }\end{array}$ & Sapotaceae & Moh & $\begin{array}{l}2 \mathrm{~cm} \text { stem bark powder is } \\
\text { soaked in } 1 \text { glass of water } \\
\text { overnight. In morning, a pinch } \\
\text { of white pepper powder and } \\
\text { cumin seed powder is added } \\
\text { and taken at empty stomach. } \\
\text { This is taken once in a week. } \\
\text { Total } 60 \text { doses are required. }\end{array}$ & 11 \\
\hline 59 & $\begin{array}{l}\text { Mangifera } \\
\text { indica } \mathrm{L} \text {. }\end{array}$ & Anacardiaceae & Amba & Flowers. & 19 \\
\hline 60 & $\begin{array}{l}\text { Mentha spicata } \\
\text { L. }\end{array}$ & Lamiaceae & Pudina & $\begin{array}{l}\text { Fresh leaves should be taken } \\
\text { with salt after a particular } \\
\text { interval of day. }\end{array}$ & 8 \\
\hline 61 & $\begin{array}{l}\text { Meyna laxiflora } \\
\text { Robyns, Bull. } \\
\text { Jard }\end{array}$ & Rubiaceae & Alu, Helu & $\begin{array}{l}\text { Five pinches of seed powder is } \\
\text { mixed with water and given } \\
\text { twice a day for } 15 \text { days. }\end{array}$ & 13 \\
\hline 62 & $\begin{array}{l}\text { Mimosa pudica } \\
\text { L. }\end{array}$ & Mimosaceae & Lajalu, Lajwanti & $\begin{array}{l}\text { - Leaf juice is added in tea and } \\
\text { used time to time. } \\
\text { - Root powder is given before } \\
\text { breakfast. }\end{array}$ & 8 \\
\hline 63 & $\begin{array}{l}\text { Momordica } \\
\text { diocia Roxb. ex. } \\
\text { Willd. }\end{array}$ & Cucurbitaceae & Kartoli & Roots, Fruits. & 19 \\
\hline 64 & $\begin{array}{l}\text { Mucuna } \\
\text { pruriens (L.) DC. }\end{array}$ & Papilionaceae & Khaj Kuiri & Roots, Seeds. & 19 \\
\hline 65 & $\begin{array}{l}\text { Murraya } \\
\text { Koenigii L. }\end{array}$ & Rutaceae & Kurry patta & Leaves. & 4 \\
\hline 66 & $\begin{array}{l}\text { Ocimum } \\
\text { sanctum } \mathrm{L} .\end{array}$ & Lamiaceae & Tulas & Leaves juice + Honey. & 19 \\
\hline 67 & $\begin{array}{l}\text { Ocimum } \\
\text { tenuiflorum } \mathrm{L} .\end{array}$ & Lamiaceae & Tulsi, Tulas & $\begin{array}{l}\text { Entire plant should burn and } \\
\text { ash mixed with water is given } \\
\text { thrice a day. }\end{array}$ & 8 \\
\hline 68 & $\begin{array}{l}\text { Phyllanthus } \\
\text { amarus Schum. } \\
\& \text { Thonn. }\end{array}$ & Euphorbiaceae & Bhui Awali & Whole plant. & 19 \\
\hline 69 & $\begin{array}{l}\text { Phyllanthus } \\
\text { fraternus } \\
\text { (Webster.) }\end{array}$ & Euphorbiaceae & Bhuiawala & $\begin{array}{l}\text { - Whole plant. } \\
\text { - Plant extract is given orally } \\
\text { for 3-4 day. }\end{array}$ & 3 \\
\hline 70 & $\begin{array}{l}\text { Punica } \\
\text { granatum L. }\end{array}$ & Punciaceae & Anar, Dalimb & $\begin{array}{l}\text { Seed juice is given before } \\
\text { breakfast }\end{array}$ & 8 \\
\hline 71 & $\begin{array}{l}\text { Raphanus } \\
\text { sativus } \\
\text { Domin }\end{array}$ & Brassicaceae & Mula & $\begin{array}{l}\text { - Root juice is given after } \\
\text { meals. } \\
\text { - Leaf juice is given before } \\
\text { breakfast. } \\
\text { - Seed powder is useful before } \\
\text { breakfast. }\end{array}$ & 8 \\
\hline 72 & $\begin{array}{l}\text { Sesamum } \\
\text { orientale L. }\end{array}$ & Pedaliaceae & Til & $\begin{array}{l}\text { Half cup of fruit juice is mixed } \\
\text { with three spoonful honey and } \\
\text { one cup of cow milk is given } \\
\text { thrice in a day for one week. }\end{array}$ & 6 \\
\hline 73 & $\begin{array}{l}\text { Sida cordifolia } \\
\text { L. }\end{array}$ & Malvaceae & Chikana & Roots. & 19 \\
\hline 74 & $\begin{array}{l}\text { Solanum nigrum } \\
\text { L. }\end{array}$ & Solanceae & Makoi & Fruits. & 19 \\
\hline 75 & $\begin{array}{l}\text { Spinacia } \\
\text { oleracea L. }\end{array}$ & Chenopodaceae & Palak. & $\begin{array}{l}\text { Half cup of leaf decoction is } \\
\text { administered twice a day for } \\
\text { three days. }\end{array}$ & 6 \\
\hline
\end{tabular}




\begin{tabular}{|c|c|c|c|c|c|}
\hline 76 & $\begin{array}{l}\text { Tamarindus } \\
\text { indica } \mathrm{L} \text {. }\end{array}$ & Caesalpiniaceae & Imli, Chinch & $\begin{array}{l}\text { Dry exocarp of the pod is boiled } \\
\text { in the water; this filte red wate } r \\
\text { is given twice a day. }\end{array}$ & 8 \\
\hline 77 & $\begin{array}{l}\text { Tectona grandis } \\
\text { (L.f.) Lam. }\end{array}$ & Lamiaceae & Sagwan, Sag & $\begin{array}{l}\text { - Mixture of seed powder, cow's } \\
\text { milk and ghee is used. } \\
\text { - } 10 \text { g seed powder with } 50 \mathrm{ml} \text { of } \\
\text { cow milk is given orally twice } \\
\text { a day for eight days. }\end{array}$ & $\begin{array}{l}2,6 \\
20\end{array}$ \\
\hline 78 & $\begin{array}{l}\text { Tephrosia } \\
\text { purpurea } \\
\text { Pers. }\end{array}$ & Fabaceae & $\begin{array}{l}\text { Sharapunkha, } \\
\text { Unhali }\end{array}$ & $\begin{array}{l}\text { - Root powder or juice is use ful } \\
\text { if taken morning and evening. } \\
\text { - Leaf decoction (one glass) } \\
\text { be fore breakfast is given. } \\
\text { - Entire plant boiled and juice } \\
\text { is given after particular } \\
\text { intervals. }\end{array}$ & 8 \\
\hline 79 & $\begin{array}{l}\text { Terminalia } \\
\text { arjuna } \\
\text { (Roxb.)Wight \& } \\
\text { Arn. }\end{array}$ & Combretaceae & Arjun, Sadada & $\begin{array}{l}\text { Bark powder is given after } \\
\text { breakfast, lunch and dinner. }\end{array}$ & $\begin{array}{l}8 \\
19\end{array}$ \\
\hline 80 & $\begin{array}{l}\text { Tinospora } \\
\text { cordifolia } \\
\text { (Wild.L) }\end{array}$ & Me nispe rmaceae & Gugul & $\begin{array}{l}\text { Crushed stem is given orally to } \\
\text { expel the stone. }\end{array}$ & 3 \\
\hline 81 & $\begin{array}{l}\text { Tribullus } \\
\text { terrestris L. }\end{array}$ & Zygophyllaceae & $\begin{array}{l}\text { Gokharu, } \\
\text { Sarata }\end{array}$ & $\begin{array}{l}\text { - Roots, Fruits } \& \text { Seeds. } \\
\text { - One teaspoon fruit powder is } \\
\text { given orally twice a day for } \\
\text { three days. } \\
\text { - Leaves decoction is taken in } \\
\text { morning and evening. } \\
\text { - Fruit juice or extract is used } \\
\text { in morning and evening. }\end{array}$ & $\begin{array}{l}3,6 \\
8 \\
15 \\
19\end{array}$ \\
\hline 82 & $\begin{array}{l}\text { Tridex } \\
\text { procumbens L. }\end{array}$ & Asteraceae & Kambarmodi & Leaf pas te is given. & 3 \\
\hline 83 & Zea mays L. & Poaceae & Maka & Tassel given orally. & 3 \\
\hline
\end{tabular}

\section{References:}

1. A.N.Korpenwar and S.U.Borkar (2011). Indigenous Medicinal Plants Used by Traditional Healers of Buldhana Tahsil, Dist. Buldhana (M.S.). In ternational Journal of Recent Trends in Science and Technology Vol. 1 (1): pp 14-19. E-ISSN: 2249-8109.

2. A.S. Lodha (2016). Traditional Medicinal Plant Resources from Maval Taluka, District Pune, Maharashtra, India. Int. J. Res. Ayurveda Pharm. Vol. 7 (3): pp 87-91.

3. Anand Tiwari, Vivek Soni, Vikas Londhe, Ashish Bhandarkar, Deepti Bandawane, Sonali Nipane (2012). An Overview on Potent Indigenous Herbs for Urinary Tract infirmity; Urolithiasis. Asian Journal of Pharmaceutical and Clinical Research Vol. 5 (1): pp 7-12. ISSN: 0974-2441.

4. B.D.Talele, R.T.Mahajan, M.Z.Chopda and N.V.Nemade (2012). Nephroprotective Plants: a Review Vol. 4 (1): pp 8-16. ISSN: 0975-1491.

5. Cox P.A.Cox (1997). Nafanua: Saving the Samoan rain forest. WH Freeman publications, Boston, England.
6. D.P.Ghorband and S.D. Biradar (2012). Traditional Healthcare Practices among the Tribe of Kinwat Range Forest of Nanded District. Indian Jou rnal of Plant Sciences Vol. 1 (2-3): pp 85-89. ISSN: 2319-3824

7. H.M.Patil and V.V.Bhaskar (2005). Medicinal uses of plants by tribal medicine men of nandurbar district in Maharashtra. Natural Product Radiance Vol. 5 (2): pp 125130.

8. I.H.Zahid, A.S.Bawazir and Rafiuddin Naser (2013). Plant based native the rapy for the treatment of Kidney stones in Aurangabad (M.S). Joumal of Pharmacognosy and Phytochemistry Vol. 1 (6): pp 189-193. ISSN: 2278- 4136.

9. K.J.Kore, R.V.Shete, P.J.Jadhav and M.P.Kabra (2011). Antiu rolithiatic Effects of Hydroalcoholic Extract of lawsonia inermis $l$ Leaves. International Joumal of Universal Pharmacy and Life Sciences Vol.1 (2): pp 81 95.

10. M.S.Khandare (2016). Mango (Mangifera indica Linn) A medicinal and holy plant. 
Joumal of Medicinal Plants Studies Vol. 4 (4): pp 44-46. ISSN: 2320-3862.

11. P.D.Shiragave (2015). Survey of Medicinal Plants used by Local People of Gadhinglaj Tahsil of Maharashtra. Journal of Global Biosciences Vol. 4 (1): pp 1795-1803. ISSN: 2320-1355.

12. P.G.Dhawale and B.P.Garhye (2015). Ethnomedicinal Survey of Yavatmal District (MS). Asian Journal of Pharmaceutical Science \& Technology Vol. 5 (3): pp 188-193. E-ISSN: 2248-9185.

13. Quazi Majaz and Molvi Khurshid I. (2014). Preliminary Phytochemical Evaluation of Leaves of Meyna laxiflora. International Research Journal of Pharmacy Vol. 5 (9): pp 676-678. ISSN: $2230-8407$.

14. R.E.Schultes (1962). The role of the ethnobotanist in the search for new medicinal plants, Lloydia, Vol. 25, pp 257 266.

15. R.Suryavanshi, M.Bachulkar and S.A.Apate (2011). Medicinal Weeds of Jowar and Pomegranate Fields from Solapur District, Maharashtra. Nature environment and pollution technology, Vol. 10 (1): pp 123-125. ISSN: 0972-6268.

16. R.U.Shaikh, D.D.Dukare, K.P.Sarwade and P.P.Sarwade (2014). Ethnobotanical Study of Folk Medicinal Plants used by Villagers in Nanded District of Maharashtra (India). International Joumal of Ayurvedic and Herbal Medicine Vol. 4 (5): pp 1585-1595. ISSN: 2249-5746. AlJournal

17. S. D.Wadje, M.R.Mali and D.Y.Gond (2014). Ethnomedicinal Plant Re sources of MahurKinwat Region of Nanded Dist. Maharashtra. International Journal of Institutional Pharmacy and Life Sciences Vol. 4 (5): pp 14-19. ISSN: 2249-6807.
18. S.A.Deshmukh and D.K.Gaikwad (2014). A review of the taxonomy, ethnobotany, phytochemistry and pharmacology of Basella alba (Basellaceae). Journal of Applied Pharmaceutical Science Vol. 4 (01): pp 153-165. ISSN: 2231-3354.

19. S.N.Patole (2015). Medicinal Plants of Akot Tahsil Used for the Treatment of Kidney Disorders. International Journal of Innovation Sciences and Research Vol.4 (7): pp 331-334.

20. S.R.Kshirsagar (2016). Ethnobotanical and Ethnomedicinal Plants of Kelzar and Tatani Forest Areas in Nasik district, Maharashtra. International Joumal of Science Info (IJSI) Vol. 1 (2): pp 95-100. ISSN: 2455-4367.

21. S.Y.Kamble, P.S.Sawant, S.R.Patil, S.G.Pawar and E.A.Singh (2014). Traditional herbal remedies practiced by the herbal healers in the tribal re gions of MaharashtraIndia. International journal of lifesciences, Vol. 2 (4): pp 334-340. ISSN: 2320-7817.

22. U.H.Patil and D.K.Gaikwad (2011). Medicinal Profile of a Scared Drug in Ayurveda: Crataeva religiosa. J. Pharm. Sci. \& Res. Vol.3 (1): pp 923-929.

23. V.H.Chungde, C.G.Kulkarni, P.H.Jadhav, P.S.Dhekale and Satyajeet Salunke (2012). Urinary Calculi Dissolving Activity of Indian Herbs- An In Vitro Study: A Step towards Rationalization. Research Joumal of Pharmaceutical, Biological and Chemical Sciences. Vol. 3 (4): pp 1001-1007. ISSN: 0975-858.

24. V.R.Deshmukh and S.P.Rothe (2013). Exotic Medicinal Plants from West Vidarbha Region VIth. Biolife Vol. 2 (1): pp 387-391. ISSN: 2320-4257. 